\title{
The Dynamics of Dermatitis Presentation Across the Ages in a Tropical Dermatology Practice in Nigeria
}

\author{
Salami T.A.T ${ }^{1}$, Akinkugbe A. ${ }^{2}$ \\ ${ }^{1}$ Departments of Internal Medicine (Dermatology Unit) Irrua Specialist Teaching Hospital IrruaEdo State, Nigeria \\ ${ }^{2}$ Departments of Internal Medicine, Lagos University Teaching Hospital, Lagos State, Nigeria \\ tatsalami@gmail.com
}

Abstract: Dermatitis as an inflammatory skin disorder is characterized by erythema and scaling of the cutaneous surface of the body. The pattern of occurrence differs across the ages and varies in different parts of the body.

The records of all patients with a diagnosis of dermatitis presenting to the dermatologic clinic of Irrua Specialist Teaching Hospital, Irrua Edo State Nigeria over a ten years period between April 2005 and April 2015 were reviewed and analyzed retrospectively and subjected to simple statistical analysis.

One thousand six hundred and twenty patients (1620) with various types of dermatitis were seen during this period representing $22 \%$ of all dermatologic presentations. Among the different types of dermatitis encountered, atopic dermatitis accounted for the highest prevalence at $28.1 \%$ occurring equally in the young and the old, followed by contact dermatitis occurring in $18.2 \%$ of the patients (mainly in young adults). Those with the lowest prevalence were stasis dermatitis $(2.4 \%)$ and asteatotic eczema (3.6\%) both occurring majorly in the elderly. Seborrhoiec dermatitis (8\%) and onchodermatitis (5\%) were the major infective dermatitis found.

The spread of dermatitis in a tropical dermatology practice from this study varies greatly among different age groups and several factors such as inherent immunity and various environmental conditions from activities of daily living are responsible for these and the knowledge of this variation may help to exclude other lesions such as psoriasis and drug eruptions which can present with a similar clinical picture.

Keywords: Dermatitis; Presentation; Ages; Nigeria.

\section{INTRODUCTION}

Dermatitis is an inflammatory skin disorder presenting with erythema and scaling of the cutaneous surface of the body. It may be primary or secondary to a variety of underlying medical conditions or medications ${ }^{1}$. It may also be acute or chronic depending on the duration before presentation. There are various ways in which dermatitis presentations may be classified ranging from the part or extent of the body affected, etiologic agent, and duration before presentation.

The occurrence of dermatitis in different parts of the body varies across the ages and from one part of the world to the other. While some variants such as atopic dermatitis appear commoner in the young ${ }^{2}$, others like exfoliative and asteatotic dermatitis appears commoner with advancing ages ${ }^{1}$.

The underlying mechanism of the different types of dermatitis appears to be linked to the activity of the immune system ${ }^{3}$ at different stages of life, however, type 1 and 3 immunologic mechanisms appears to be more prominent in their manifestation ${ }^{3}$. There are usually no sex differences except for regional affectation in areas such as the nipples or genitalia ${ }^{4}$.

This study aims to looks at the dynamics of such presentation across the ages in a tropical dermatologic practice in Nigeria and compare the findings to that from other places where the prevalence of dermatitis had been previously documented. 
The Dynamics of Dermatitis Presentation Across the Ages in a Tropical Dermatology Practice in Nigeria

\section{MATERIALS AND METHODS}

The records of all patients with a diagnosis of dermatitis who presented to the dermatologic clinic of Irrua Specialist Teaching Hospital Irrua Edo State Nigeria over a ten years period (April 2005- April 2015) were analysed. Data was obtained from the records. This included socio-demographic and relevant clinical data. These were subjected to simple statistical analysis using Epi-info 2007. Institutional consideration was granted by the Ethical committee of the hospital.

\section{RESULTS}

A total of 7350 dermatologic patients were seen during the ten year period. One thousand six hundred and twenty (1620) of these presented with various types of dermatitis representing $22 \%$ of all dermatologic presentations.

See table beneath for distribution

\begin{tabular}{|c|c|c|c|c|c|c|c|c|c|c|c|c|}
\hline $\begin{array}{l}\text { TYPE OF } \\
\text { DERMATITIS }\end{array}$ & \begin{tabular}{|l|}
$<1$ \\
year
\end{tabular} & $\begin{array}{l}1-5 \\
\text { years }\end{array}$ & $\begin{array}{l}\text { 6-10 } \\
\text { years }\end{array}$ & $\begin{array}{l}11-20 \\
\text { Years }\end{array}$ & $\begin{array}{l}21-30 \\
\text { years }\end{array}$ & $\begin{array}{l}31-40 \\
\text { years }\end{array}$ & 41- 50 years & $\begin{array}{l}51-60 \\
\text { years }\end{array}$ & $\begin{array}{l}61-70 \\
\text { years }\end{array}$ & $\begin{array}{l}71-80 \\
\text { years }\end{array}$ & $\begin{array}{l}81-90 \\
\text { years }\end{array}$ & TOTAL \\
\hline Atopic & 15 & 40 & 59 & 80 & 100 & 41 & $\begin{array}{l}120 \text { Chronic } \\
(43)\end{array}$ & & & & & $455(28.1 \%)$ \\
\hline Contact & & & 21 & 38 & \begin{tabular}{|l}
62 \\
Infected \\
-38
\end{tabular} & $\begin{array}{l}\text { Plantar-19 } \\
\text { Nipple-17 }\end{array}$ & 80 & 20 & & & & $295(18.2 \%)$ \\
\hline Serb Derm & 25 & & & & 23 & 23 & 21 & 18 & & 20 & & $130(8 \%)$ \\
\hline Exfoliative & & & & & 17 & 40 & 19 & 22 & 81 & 60 & 25 & $264(16.3 \%)$ \\
\hline Phytophoto & & & & 22 & & & & & 19 & & 15 & $56(3.5 \%)$ \\
\hline Palmoplantar & & & & & 97 & & & & & & & $97(6 \%)$ \\
\hline $\begin{array}{l}\text { Lichen simplex } \\
\text { chronicus }\end{array}$ & & & & 19 & 63 & & 22 & & 40 & & & $144(8.9 \%)$ \\
\hline Stasis & & & & & & & 18 & 20 & & & & $38(2.4 \%)$ \\
\hline Asteatotic & & & & & & & & & 20 & 19 & 20 & $59(3.6 \% 4)$ \\
\hline Onchodermatitis & & & & 21 & 20 & & & & & 41 & & $82(5 \%)$ \\
\hline TOTAL & 40 & 40 & 80 & 180 & 420 & 140 & 280 & 80 & 160 & 140 & 60 & $1620(100 \%)$ \\
\hline
\end{tabular}

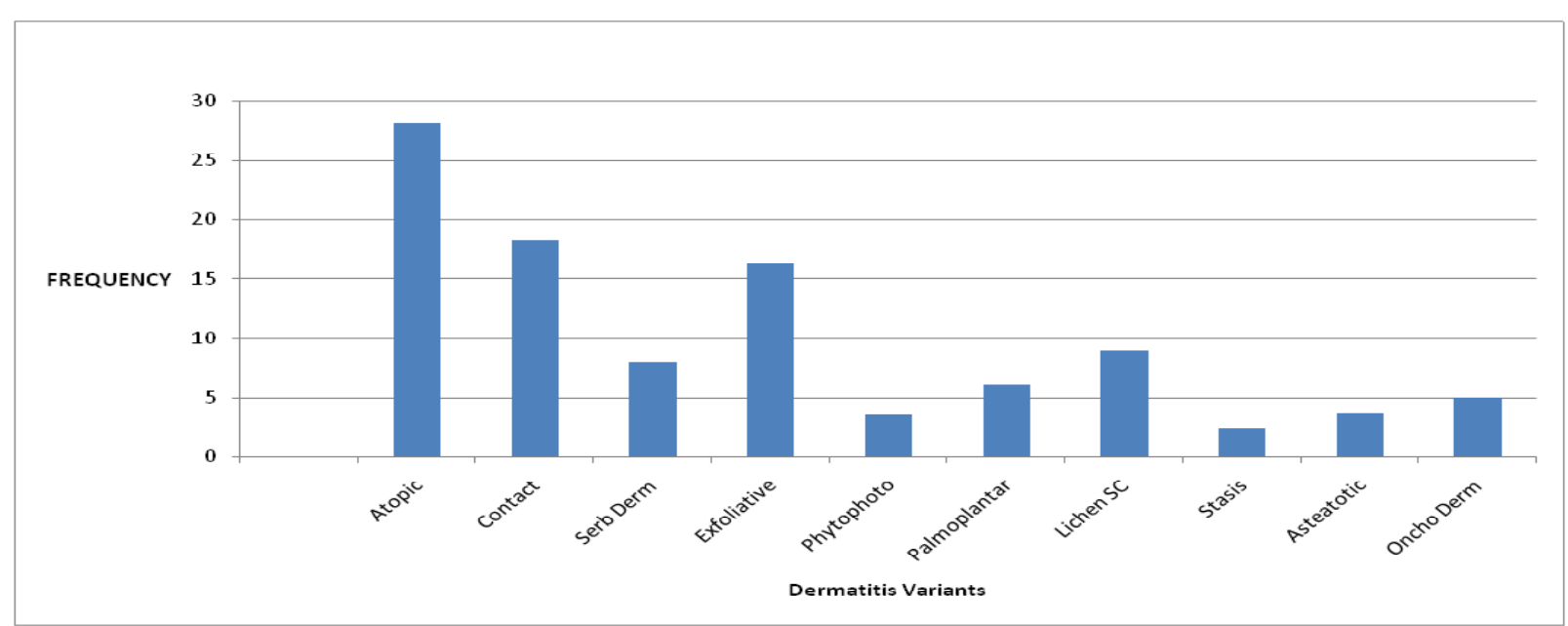

Fig1. Occurrence of Different Types of Dermatitis Encountered 
The Dynamics of Dermatitis Presentation Across the Ages in a Tropical Dermatology Practice in Nigeria

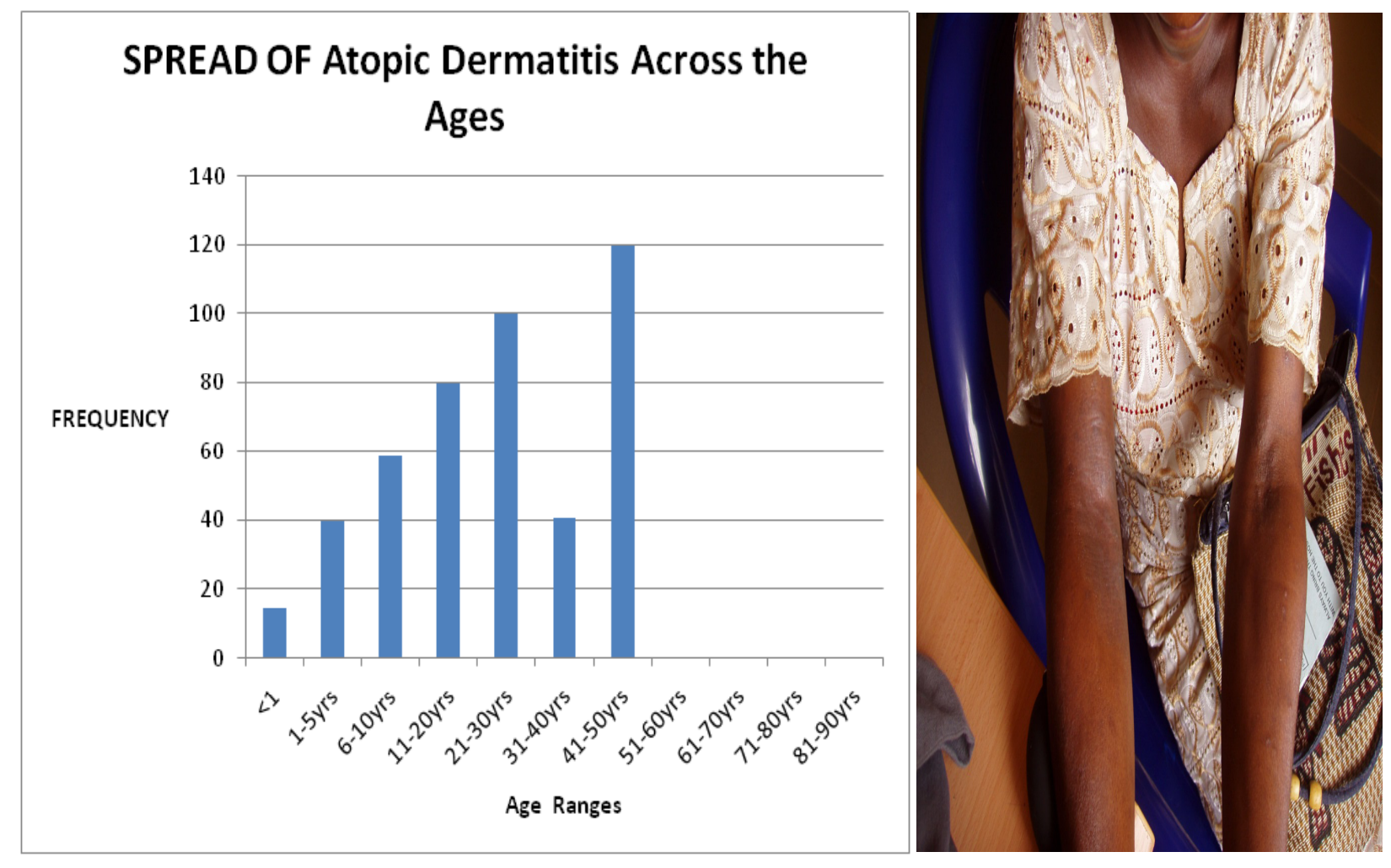

Typical flexural distribution in adults.

Fig2. Distribution of Atopic dermatitis across the age groups

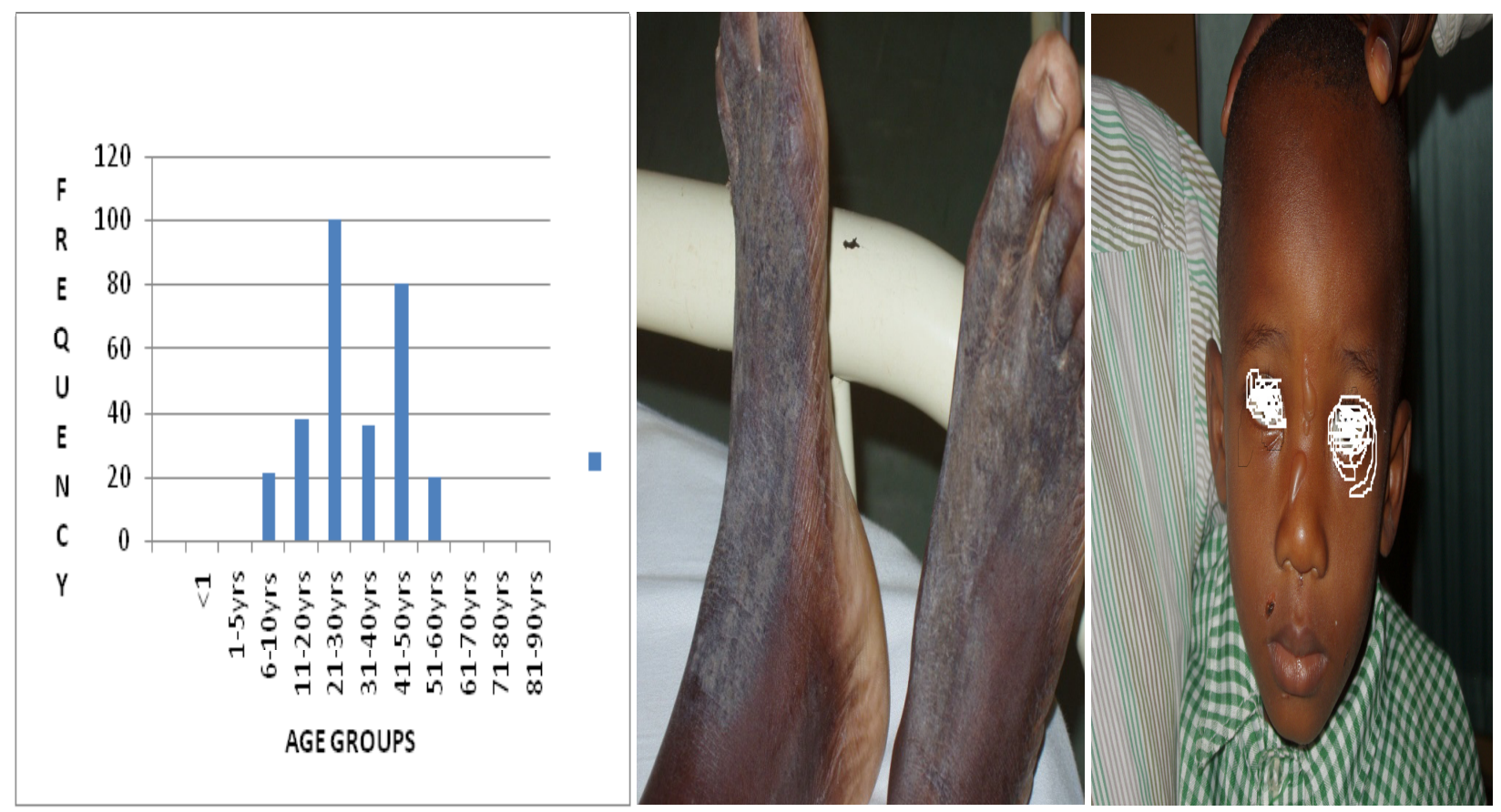

Bilateral chronic shoe dermatitis Acute bullae of phytodermatitis

Fig3. Distribution of Contact Dermatitis Across the Age Groups 
The Dynamics of Dermatitis Presentation Across the Ages in a Tropical Dermatology Practice in Nigeria
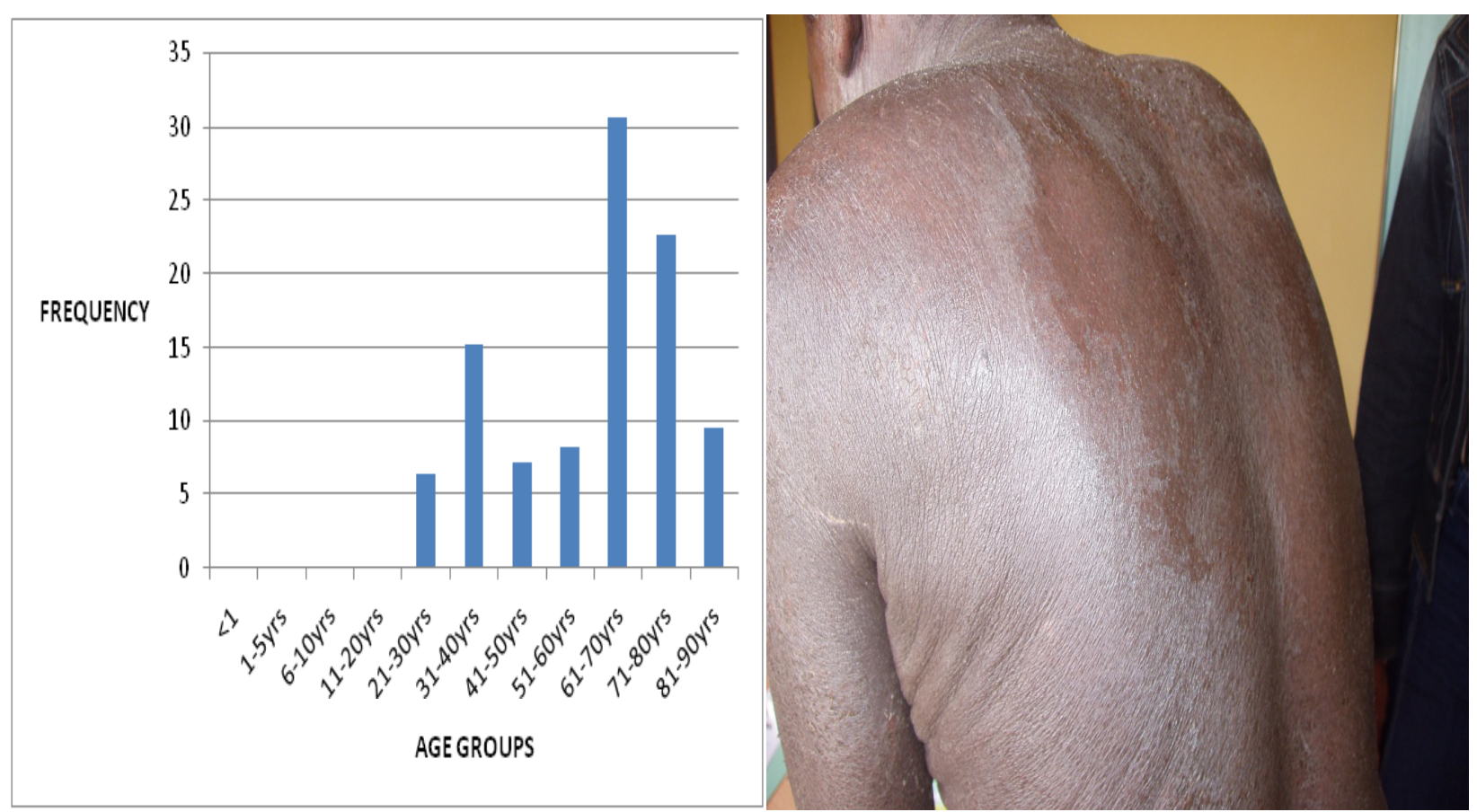

Exfoliative dermatitis('powdery' fine scales)

Fig4. Exfoliative Dermatitis Distribution

\section{DiscusSion}

The prevalence of dermatitis found in this study is $22 \%$ compared to other dermatologic presentations. This is similar to the $20.9 \%$ found by Ubonu et al in Benin- city ${ }^{5}$ probably due to the similar population and proximity (in the same state) to our centre. It is however different from the $27 \%$ prevalence found by Akinboro et al in $0^{0} \operatorname{sogbo}^{6}$ (south west Nigeria) and the $35 \%$ found by Yahya in Kaduna ${ }^{7}$ (north central Nigeria). This is possibly a reflection of the dynamic nature of dermatitis among different geopolitical zones of the country. It also confirms the importance of dermatitis as a significant clinical presentation to the average dermatologic clinic as reported from other parts of Nigeria by other researchers as well ${ }^{8-10}$.

Atopic dermatitis accounted for the commonest type of dermatitis seen in this study occurring in $28 \%$ of patients with dermatitis. This is similar to the $29.8 \%$ reported by Akinboro et al ${ }^{6}$ but contrasts with the $13.8 \%$ found by $\mathrm{Yahya}^{7}$, and the $7.92 \%$ found by Onunu et al ${ }^{11}$ respectively. Atopic dermatitis however represents only $6.1 \%$ of all dermatologic presentation. This is similar to the $8.5 \%$ reported by Nnoruka in Enugu, south east Nigeria ${ }^{12}$. In some parts of the world the prevalence of atopic dermatitis appears to be lower such as in Singapore as reported by Tay et $\mathrm{al}^{13}$ where a prevalence of $2 \%$ was found. This may be due to the different geographical location of the study site compared to ours and perhaps less environmental allergic stimulants as found in Africa. However atopic dermatitis has been found to be the commonest type of dermatitis both in Nigeria ${ }^{14}$ as well as other parts of the world. Ayala et al also found a prevalence of $13.5 \%$ of atopic dermatitis among their patients ${ }^{15}$ thus corroborating the high prevalence of atopic dermatitis documented from most parts of the world ${ }^{15}$. In our study, atopic dermatitis affects the 21- 30 year age group more than the other ages. This may be due to the predominantly adult nature of the dermatology clinic in our centre as this age bracket also has the highest prevalence of the various types of dermatitis presentation (25.6\%). 
The Dynamics of Dermatitis Presentation Across the Ages in a Tropical Dermatology Practice in Nigeria

Contact dermatitis is the second commonest type of dermatitis found in this study occurring in $18.21 \%$ of patients presenting with dermatitis. This is in contrast to the $12.3 \%$ prevalence reported by Olumide in Lagos south west Nigeria ${ }^{16}$. Also, Ayanlowo et $\mathrm{al}^{17}$ found a prevalence of $7.7 \%$ of allergic contact dermatitis among patients investigated with patch testing in Lagos, Nigeria. Contact dermatitis in adults has been largely related to the various occupational activities of adult patients. This has been extensively studied by foremost workers on this subject like Olumide et al in various publications ${ }^{18-22}$. The commonest age group affected is also the 21-30 years old age group (33.3\%). This age group is likely to be affected by contact dermatitis compared to others because young adults constitute the group most involved with occupational and aesthetic activities that are likely to predispose them to the various types of contact dermatitis from different agents. Forty percent (40\%) of our patients presented with infected irritant contact dermatitis lesions showing the propensity of this type of lesions to become secondarily infected. Irritant contact dermatitis which is a non-specific inflammatory dermatitis brought about by activation of the innate immune system by the pro-inflammatory properties of irritants is the most common type of contact dermatitis reported from most studies in Nigeria ${ }^{16-22}$. This type is majorly due to occupational activities as noted by Soyinka in his study of this disorder among bricklayers ${ }^{23-24}$ while allergic contact dermatitis is a delayed-type hypersensitivity response with a skin inflammation mediated by hapten-specific T cells ${ }^{25}$. Olumide had earlier noted the very high prevalence of occupational contact dermatitis in various parts of the body in her research on contact dermatitis in Lagos, Nigeria ${ }^{18-22}$. This ranges from $10.7 \%$ hand dermatitis alone ${ }^{18}$ with $20.4 \%$ occurring in men $^{19}$ as a result of their various occupational pursuits. $13 \%$ of neck dermatitis was reported from necklaces ${ }^{20}$ and $61 \%$ of feet dermatitis was detected by patch testing ${ }^{21}$. Patch testing has been used to study the prevalence of this type of contact dermatitis by Ayanlowo et al and Olumide in Lagos Nigeria ${ }^{17,18} .71 .4 \%$ of feet dermatitis was confirmed by patch testing to be of the allergic contact dermatitis variant by Olumide in Lagos ${ }^{21}$.

In this study $6 \%$ of our patients presented with palmoplantar dermatitis perhaps related to the significant farming population in this rural community. Omokhodion et al had reported a prevalence of $5 \%$ hand dermatitis among hairdressers in Ibadan south west Nigeria ${ }^{22}$ confirming the occupational predisposition to some types of contact dermatitis. Phytophoto dermatitis was observed in $3 \%$ of our patients which were mostly children largely from contact with flowers and plants in schools where they are used to improve the aesthetic, landscaping appearance of the environment. Similarly regional contact dermatitis such as Nipple dermatitis (5.8\%) in this study was found in young women from brassieres and breastfeeding.

In this study exfoliative dermatitis occurred in $16.3 \%$ of our patients with dermatitis. It has a bimodal age distribution occurring in 31\% of the $61-70$ years old, $23.1 \%$ in the $71-80$ years old and $15.4 \%$ in the younger age group of 30-40 years old. This pattern of distribution had earlier been observed by Salami et $\mathrm{al}^{26}$ and may be due to increasing suspicion of underlying occult malignancies among patients advanced in age/ or elderly patients presenting with exfoliative dermatitis while cutaneous drug reactions particularly in patients with HIV infection in the more sexually active younger age group of 30-40 years may be responsible for this in young adults $^{27}$. A similar pattern in young adults with HIV infection has also been reported by other researchers from other parts of Nigeria ${ }^{28-30}$.

Lichen simplex chronicus (LSC) (picture below) was found in $8.9 \%$ of our patients with dermatitis in this study. It was noted mostly among the 21- 30 years age bracket where it affected $43 \%$ of patients followed by $29 \%$ in the 61-70 years age group. This is in contrast to the 3\% found by Yahya in Kaduna Nigeria and Bilgi et al in Turkey ${ }^{7,31}$. Liao et at had also noted a preponderance of LSC among elderly patients with anxiety disorder particularly those with obsessive compulsive disorders in a population study in China ${ }^{32}$. LSC has also been observed by An et al to impart negatively on the quality of life of affected patients ${ }^{33}$. 


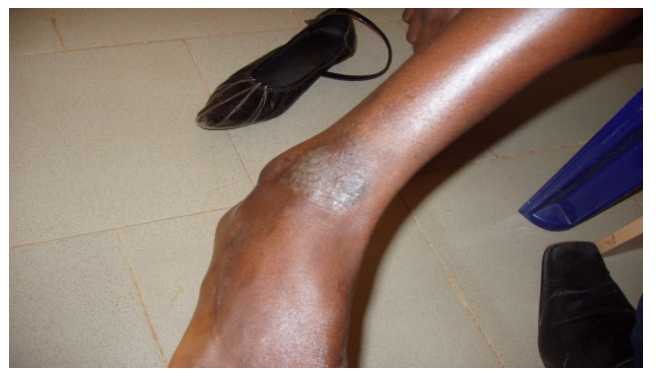

Asteatotic dermatitis (see below) is another type of dermatitis seen commonly in elderly patients as a result of the increased dryness of the skin due to the less moisturizing nature of the skin with advancing ages leaving the skin dry and prone to itching. It was found in $3.6 \%$ of our patients and this was mainly in the 60 years and above age group. This is roughly half of the $6.5 \%$ prevalence reported by Ayala et al in their patients ${ }^{15}$. This may be due to the presence of more elderly patients in developed countries due to the longer life span compared to that in the developing countries like Nigeria.
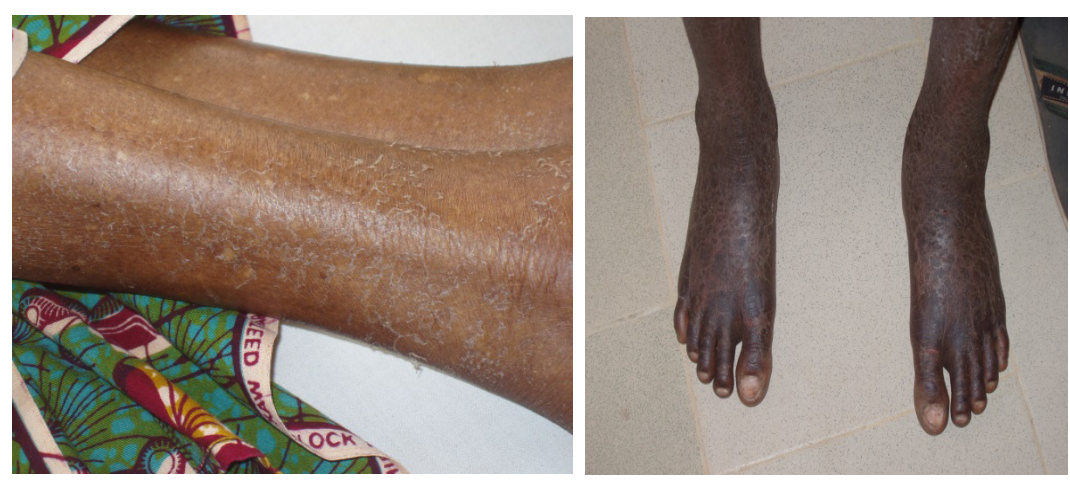

Similarly stasis dermatitis (see below) accounted for $2.35 \%$ prevalence in our study possibly due to similar reasons.

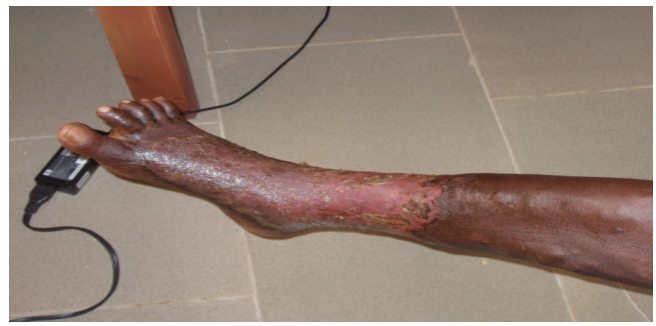

Among the infective dermatitis, seborrhoeic dermatitis (SD) occurred the most in this study. It was present in $8.03 \%$ of patients presenting with dermatitis and occurs fairly equally between the ages of 21-60 years.

This is similar to the $6.3 \%$ found by Ayala et $\mathrm{al}^{15}$ but contrasts to the $2.2 \%$ found by Bilgi et al in Turkey ${ }^{31}$.

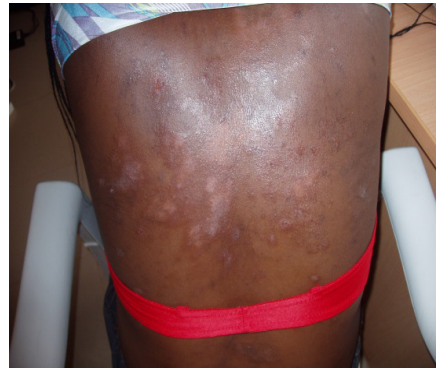


The Dynamics of Dermatitis Presentation Across the Ages in a Tropical Dermatology Practice in Nigeria

SD in adults is among the common cutaneous manifestations of HIV infection in Nigeria ${ }^{30,34}$.

Only $16.7 \%$ of infantile seborrhoeic dermatitis was seen in this study and this could be attributed to the fact that this condition is less symptomatic than atopic dermatitis and they are more likely to present to the peadiatrician.

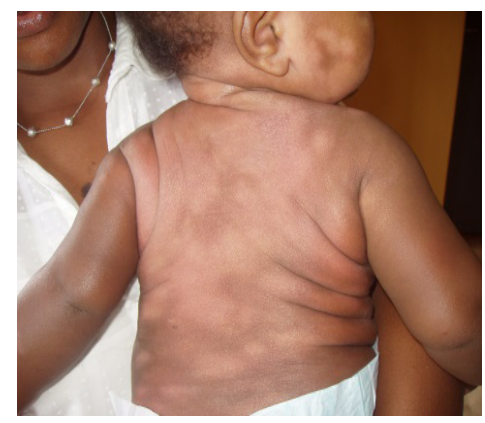

Onchodermatitis was present in only $5.07 \%$ of our patients. This may be due to the lesser skin affectation compared to other parts of the body such as the eyes ${ }^{35}$ and the lymphatics ${ }^{36}$ and also with the previous intense therapeutic campaigns launched to eradicate the infection in this country ${ }^{37}$.

\section{CONCLUSION}

In conclusion the various manifestations of dermatitis are well documented locally; however their prevalences differ across the ages and in different parts of the world. The knowledge of the spread of dermatitis across the different age groups may help in ascertaining the likely etiology and result in better management for the individuals. This knowledge will also assist dermatologists to whom this condition can present a challenge.

LIMITATIONS. This is majorly an observational study among patients presenting to the adult dermatologic clinic and may not be reflective of the spread of dermatitis in the larger community. However the 10 years duration of the observation may partially compensate for this.

ACKNOWLEDGEMENT. To the staff of the medical records department of the hospital for allowing access to the medical records of the patients used in this study.

\section{REFERENCES}

1. Pal S, Haroon TS. Erythroderma: a clinico-etiologic study of 90 cases. Int J Dermatol. 1998 Feb;37(2):104-107.

2. Eichenfield LF, Hanifin JM, Beck LA, Lemanske RF Jr, Sampson HA, Weiss ST, Leung DY. Atopic dermatitis and asthma: parallels in the evolution of treatment. Pediatrics. 2003 Mar;111(3):608-616.

3. Oakes RC, Cox AD, Burgdorf WH. Atopic dermatitis. A review of diagnosis, pathogenesis, and management. Clin Pediatr (Phila). 1983 Jul;22(7):467-475.

4. Rajalakshmi R, Thappa DM, Jaisankar TJ, Nath AK. Lichen simplex chronicus of anogenital region: a clinicoetiological study. Indian J Dermatol Venereol Leprol. 2011 Jan-Feb;77(1): 28-36.

5. Ukonu AB, Eze EU. Pattern of skin diseases at university of Benin teaching hospital,Benin City, Edo State, South-South Nigeria: a 12 month prospective study. Glob J Health Sci.2012 Apr 28;4(3):148-157.

6. Akinboro AO, Mejiuni AD, Akinlade MO, Audu BM, Ayodele OE. Spectrum of skin diseases presented at LAUTECH teaching hospital , Osogbo, southwest Nigeria. Int J Dermatol. 2015 Apr;54(4):443-450

7. Yahya H. Change in pattern of skin disease in Kaduna, north-central Nigeria. Int J Dermatol. 2007 Sep;46(9):936-943 
The Dynamics of Dermatitis Presentation Across the Ages in a Tropical Dermatology Practice in Nigeria

8. Nnoruka EN. Skin diseases in south-east Nigeria: a current perspective. Int J Dermatol. 2005 Jan;44(1):29-33

9. Ogunbiyi AO, Daramola 00, Alese 00. Prevalence of skin diseases in Ibadan, Nigeria. Int J Dermatol. 2004 Jan;43(1):31-36

10. Onayemi O, Isezuo SA, Njoku CH. Prevalence of different skin conditions in an outpatients' setting in north-western Nigeria. Int J Dermatol. 2005 Jan;44(1):7-11.

11. Onunu AN, Eze EU, Kubeyinje EP. Clinical profile of atopic dermatitis in Benin City, Nigeria. Niger J Clin Pract. 2007 Dec;10(4):326-329.

12. Nnoruka EN. Current epidemiology of atopic dermatitis in south-eastern Nigeria. Int J Dermatol. 2004 Oct;43(10):739-744.

13. Tay YK, Khoo BP, Goh CL. The profile of atopic dermatitis in a tertiary dermatology outpatient clinic in Singapore. Int J Dermatol. 1999 Sep;38(9):689-92. Olumide Y.M. The incidence of Atopic dermatitis in Nigeria.Int J Dermatol. 1986;26:367.

14. Olumide Y.M. The incidence of Atopic dermatitis in Nigeria.Int J Dermatol. 1986;26:367.

15. Ayala F, Fabbrocini G, Bacchilega R, Berardesca E, Caraffini S, Corazza M et al. Eyelid dermatitis: an evaluation of 447 patients. Am J Contact Dermat. 2003 Jun;14(2):69-74.

16. Olumide Y.M. Contact dermatitis in Nigeria. Contact dermatitis. 1986;15:241.

17. Ayanlowo 0, Olumide Y. Current pattern of patch test results at the skin clinic of the Lagos university teaching hospital, Nigeria. Int J Dermatol. 2011 Mar;50(3):372-374.

18. Olumide Y.M. Contact dermatitis in Nigeria (I). Hand dermatitis in women. Contact dermatitis. 1987;17:85.

19. Olumide Y.M. Contact dermatitis in Nigeria (II). Hand dermatitis in men. Contact dermatitis. 1987;17:136.

20. Olumide Y.M. Contact dermatitis in Nigeria (III). Dermatitis of the neck. Contact dermatitis. 1987;17:139.

21. Olumide Y.M. Contact dermatitis in Nigeria (IV). Dermatitis of the feet. Contact dermatitis. 1987;17:142.

22. Omokhodion FO, Balogun MO, Ola-Olorun FM. Reported occupational hazards and illnesses among hairdressers in Ibadan, Southwest Nigeria. West Afr J Med. 2009 Jan;28(1):20-23

23. Soyinka F. Epidemiology of occupational disease among bricklayers in Nigeria. Effects of age and duration of contact. Berufsdermatosen.1977 Oct;25(5)195-202

24. Soyinka F. Contact allergic dermatitis 'current topic in tropical dermatology'. Niger J Med. 1978 Nov;8(6):513-525.

25. Nosbaum A, Vocanson M, Rozieres A, Hennino A, Nicolas JF. Allergic and irritant contact dermatitis. Eur J Dermatol. 2009 Jul-Aug;19(4):325-332.

26. Salami T.A.T, Oziegbe O.E, Omeife H. Exfoliative dermatitis: Patterns of clinical presentation in a tropical rural and suburban practice in Nigeria. Int J Dermatol. 2012;5:1086-1089.

27. Salami T.A.T, Asalu A.F, Samuel S.O. Prevalence of cutaneous drug eruptions in adult Nigerians with HIV/ AIDS. Nigeria post grad med J 2010;17:160-163.

28. Akolo C, Ukoli CO, Ladep GN, Idoko JA. The clinical features of HIV/AIDS at presentation at the Jos university teaching hospital . Niger J Med. 2008 Jan-Mar;17(1):83-87. 
The Dynamics of Dermatitis Presentation Across the Ages in a Tropical Dermatology Practice in Nigeria

29. Ojini FI, Coker A. Socio-demographic and clinical features of HIV- positive outpatients at a clinic in southwest Nigeria. Afr J AIDS Res. 2007 Aug; 6(2):139- 145.

30. Nnoruka EN, Chukwuka JC, Anisuiba B. Correlation of mucocutaneous manifestations of HIV/AIDS infection with CD4 counts and disease progression. Int J Dermatol. 2007 Oct;46 Suppl 2:14-18.

31. Bilgi ME, Yildiz H, Sarici G. Prevalence of skin diseases in a dermatology outpatient clinic in Turkey. A cross sectional, retrospective study. J Dermatol Case Rep.2013 Dec 30;7(4)108-112.

32. Liao YH, Lin CC, Tsai PP, Shen WC, Sung FC, Kao CH. Increased risk of lichen simplex chronicus in people with anxiety disorder: a nationwide population based retrospective cohort study. Br J Dermatol. 2014 Apr;170 (4):890-894.

33. An JG, Liu YT, Xiao SX, Wang JM, Geng SM, Dong YY. Quality of life of patients with neurodermatitis. Int J Med Sci. 201310 (5):593-598.

34. Salami TAT, Adewuyi GM, Echekwube P, Affusim C. Pattern of cutaneous pathology among a cohort of HIV/ AIDS patients accessing care in a rural/suburban adult ART clinic in Nigeria. British Journal of Medicine \& Medical Research. 2013, 3(4): 1199-1207.

35. Nmorsi OP, Oladokun IA, Egwunyenga OA, Oseha E. Eye lesions and onchocerciasis in a rural farm settlement in Delta state, Nigeria. Southeast Asian J Trop Med Public Health. 2002 Mar;33(1):28-32.

36. Anosike JC, Nwoke BE, Ajayi EG, Onwuliri CO, Okoro OU, Oku EE, Asor JE, Amajuoyi OU, Ikpeama CA, Ogbusu FI, Meribe CO. Lymphatic filariasis among the Ezza people of Ebonyi State, eastern Nigeria. Ann Agric Environ Med. 2005;12(2):181-186.

37. Ogbuagu KF, Eneanya CI. A multi-centre study of the effect of Mectizan treatment on onchocercal skin disease: clinical findings. Ann Trop Med Parasitol. 1998 Apr;92 Suppl 1:S139-145

Citation: Salami T.A.T, Akinkugbe A.0, "The Dynamics of Dermatitis Presentation Across the Ages in a Tropical Dermatology Practice in Nigeria". American Research Journal of Medicine and Surgery. 2017; 3(1): 1-9.

Copyright (c) 2018 Salami T.A.T, Akinkugbe A.0, This is an open access article distributed under the Creative Commons Attribution License, which permits unrestricted use, distribution, and reproduction in any medium, provided the original work is properly cited. 